Original Research Paper

\title{
Sosialisasi Peran dan Fungsi Mangrove Pada Masyarakat di Kawasan Gili Sulat Lombok Timur
}

\author{
Agil Al Idrus ${ }^{1 *}$ M. Liwa Ilhamdi ${ }^{1}$, Gito Hadiprayitno ${ }^{1}$ dan Gde Mertha ${ }^{1}$ \\ ${ }^{1}$ Program Studi Pendidikan Biologi Jurusan Fakultas Keguruan dan Ilmu Pendidikan Universitas Mataram
}

*Corresponding Author:

Agil Al Idrus, Program

Studi Pendidikan Biologi Jurusan Fakultas Keguruan dan Ilmu Pendidikan

Universitas Mataram, Indonesia;

Email:

agil.alidrus2004@yahoo.com

\begin{abstract}
Abstrak: Mangrove merupakan salah satu tumbuhan yang sangat baik untuk menjaga keseimbangan ekosistem pantai. Saat ini banyak lokasi pantai yang sudah rusak ekosistem mangrovenya, sehingga perlu rehabilitasi mangrove. Peran dan fungsi mangrove bagi lingkungan perlu disoaialisasikan kepada masyarakat sekitar. Kegiatan pengabdian ini ditujukan untuk mensosialisasikan peran dan fungsi mangrove di masyarakat sekitar Gili Sulat. Metode yang digunakan adalah pelatihan berupa sosialisasi, diskusi, Tanya jawab. Hasil Pengabdian menunjukkan bahwa semua peserta antusias mengikuti kegiatan pengabdian yaitu sosialisasi, diskusi dan Tanya jawan tentang peran dan fungsi mangrove pada masyarakat di kawasan Gili Sulat Lombok Timur. Serangkaian kegiatan pengabdian pada masyarakat ini telah berlangsung dengan kesimpulan sebagai berikut: semua peserta yang terdiri dari warga masyarakat yang ada di sekitar Gili Sulat Lombok Timur sangat antusias mengikuti seluruh rangkaian kegiatan dengan memberikan respon positif selama kegiatan berlangsung. Tim Pengabdian memaparkan dan memberikan sosialisasi peran dan fungsi mangrove pada masyarakat di sekitar Gili Sulat dan peserta aktif menanyakan hal-hal yang belum jelas dari materi sosialisasi. Pada akhir kegiatan pengabdian masyarakat mempunyai pengetahuan yang baik tentang peran dan fungsi mangrove sehingga mereka dapat menjaga dan melestarikan ekosistem mangrove di Gili Sulat.
\end{abstract}

Kata Kunci: Peran, fungsi, Mangrove, Gili Sulat

\section{Pendahuluan}

Mangrove adalah tumbuhan khas daerah tropis yang hidupnya hanya berkembang baik pada temperatur dari $19^{\circ} \mathrm{C}$ sampai $40^{\circ} \mathrm{C}$ dengan toleransi fluktuasi tidak lebih dari $10^{\circ} \mathrm{C}$. Berbagai jenis Mangrove yang tumbuh di bibir pantai dan merambah tumbuh menjorok ke zona berair laut, merupakan suatu ekosistem yang khas. Khas karena bertahan hidup di dua zona transisi antara daratan dan lautan, sementara tanaman lain tidak mampu bertahan. Hutan Mangrove memberikan perlindungan kepada berbagai organisme lain baik hewan darat maupun hewan air untuk bermukim dan berkembang biak, melindungi pantai dari gelombang dan angin merupakan tempat yang dipenuhi pula oleh kehidupan lain seperti mamalia, amfibi, reptil, burung, kepiting, ikan, primata, serangga dan sebagainya (Arief, 2007). Ekosistem mangrove menyediakan keanekaragaman hayati (biodiversity) sebagai plasma nutfah (genetic pool) dan menunjang keseluruhan sistem kehidupan di sekitarnya. Habitat mangrove merupakan tempat mencari makan (feeding ground) bagi hewanhewan tersebut dan sebagai tempat mengasuh dan membesarkan anaknya, tempat bertelur dan memijah (spawning ground) dan tempat berlindung yang aman bagi berbagai juvenile dan larva ikan serta kerang (shellfish) dari predator ( Santoso, 2000).

Tumbuhan mangrove berperan sebagai buffer (perisai alam) dan menstabilkan tanah dengan menangkap dan memerangkap endapan material dari darat yang terbawa air sungai dan yang kemudian terbawa ke tengah laut oleh arus. Hutan mangrove mempunyai toleransi besar terhadap kadar garam dan dapat berkembang di daratan bersalinitas tinggi di mana tanaman biasa tidak dapat tumbuh. Tumbuhan mangrove 
merupakan salah satu tumbuhan yang sangat baik untuk menjaga keseimbangan ekosistem pantai (Nybakken, 1993). Saat ini banyak lokasi pantai yang sudah rusak ekosistem mangrovenya, sehingga perlu rehabilitasi mangrove. Untuk menanam kembali mangrove perlu bibit yang baik agar mangrove dapat tumbuh dengan baik dari bibit sampai dewasa.

Gili Sulat merupakan pulau di sebelah Timur bagian Utara Pulau Lombok yang secara administratif termasuk wilayah Desa Sambelia, Kecamatan Sambelia, Kabupaten Lombok Timur, Provinsi Nusa Tenggara Barat. Gili Sulat memiliki keunikan dibandingkan dengan gili lain yang ada di NTB karena banyak mengandung spesies mangrove. Beberapa hasil penelitian menunjukkan bahwa jumlah jenis mangrove yang ditemukan di Gili Sulat termasuk paling banyak di Indonesia. Gili Sulat memiliki luas 1200 hektar.

Gili Sulat dapat ditemukan tujuh jenis mangrove sejati yaitu Rhizophora stylosa, Rhizophora apiculata, Rhizophora mucronata, Bruguiera gymnorrhiza, Ceriops sp., Sonneratia alba, Avicennia marina, sepuluh jenis tumbuhan asosiasi mangrove adalah Lumnitzera racemosa, Pemphis acidula, Pongmia pinnata, Cordia subcordata, Caeslpinia bonduc, Thespesia populnea, Clerodendron inermee, Sesuvium portuclastratum, Ipomoea pes-caprae, Exoecaria agallocha (Agil et al, 2014; Agil et al., 2015). Selain itu, dari aspek ekologi spesies mangrove dapat menjadi biondikator untuk menilai akumulasi tingkat pencemaran suatu perairan dari ogam berat (Kristanti et al., 2007; Khairuddin et al., 20180) dan habitat mangrove sebagai habaiat kepiting bakau yang secara khas berasosiasi dengan hutan mangrove yang masih baik, sehingga terdegradasinya habitat akan memberikan dampak yang serius terhadap keberadaan populasi kepiting bakau (Tahmid et al., 015). Berkaitan dengan peranan penting ekosisem mangrove, tujuan kegiatan ini adalah untuk mensosialisasikan peran dan fungsi mangrove pada masyarakat sekitar Gili Sulat.

\section{Metode Pelaksanaan Kegiatan}

Metode pelaksanaan kegiatan pengabdian masyarakat ini difokuskan pada upaya penyelesaian masalah yang sedang dihadapi oleh masyarakat dalam memahami peran dan fungsi mangrove. Permasalahan tersebut dapat diatasi melalui Sosialisasi peran dan fungsi mangrove kepada masyarakat dan monitoring. Implementasi Sosialisasi peran dan fungsi mangrove kepada masyarakat akan dilakukan dalam bentuk sosialisasi, diskusi dan Tanya jawab. Sosialisasi akan dilakukan dalam bentuk penyampaian materi (teori). Peserta sosialisasi akan direkrut kelompok nelayan di sekitar Gili Sulat. Penyampaian materi dilakukan dalam bentuk klasikal. Materi yang akan disampaikan terdiri dari (1) memperkenalkan tentang ekosistem mangrove, (2) menyampaikan cara peran mangrove (3) menyampaikan fungsi mangrove.

\section{Hasil dan Pembahasan}

Kegiatan sosialisasi dilakukan di warga masyarakat sekitar Gili Sulat Lombok Timur. Peserta pelatihan terdiri dari warga masyarakat dan kelompok- kelompok nelayan yang berjumlah 19 orang. Pada kegiatan ini dilakukan penyajian materi kegiatan yaitu tentang peran dan fungsi mangrove pada masyarakat di kawasan Gili Sulat Lombok Timur. Pada saat diskusi tentang peran dan fungsi mangrove pada masyarakat sekitar kawasan Gili Sulat Lombok Timur peserta sangat antusias dalam mengikuti diskusi karena keinginan para peserta untuk tetap mempertahankan keberadaan mangrove di Gili Sulat agar lestari sehingga mereka dapat memperoleh ikan di sekitar Gili Sulat secara berkelanjutan sebagai sumber kehidupan bagi mereka di sekitar kawasan Gili Sulat.

\section{a. Hutan Mangrove dan Peranannya}

Hutan mangrove merupakan salah satu potensi sumberdaya alam hayati yang bernilai ekonomi tinggi dan sangat layak untuk dikelola lebih jauh. Hutan mangrove merupakan ekosistem yang kompleks terdiri atas flora dan fauna daerah pantai, hidup sekaligus di habitat daratan dan air laut, antara batas air pasang dan surut. Berperan dalam melindungi garis pantai dari erosi, gelombang laut dan angin topan. Tanaman mangrove berperan juga sebagai buffer (perisai alam) dan menstabilkan tanah dengan menangkap dan memerangkap endapan material dari darat yang 
terbawa air sungai dan yang kemudian terbawa ke tengah laut oleh arus. Hutan mangrove mempunyai toleransi besar terhadap kadar garam dan dapat berkembang di daratan bersalinitas tinggi di mana tanaman biasa tidak dapat tumbuh.

Mangrove adalah khas daerah tropis yang hidupnya hanya berkembang baik pada temperatur dari $19^{\circ}$ sampai $40^{\circ} \mathrm{C}$. dengan toleransi fluktuasi tidak lebih dari $10^{\circ} \mathrm{C}$. Berbagai jenis Mangrove yang tumbuh di bibir pantai dan merambah tumbuh menjorok ke zona berair laut, merupakan suatu ekosistem yang khas. Khas karena bertahan hidup di dua zona transisi antara daratan dan lautan, sementara tanaman lain tidak mampu bertahan. Hutan Mangrove memberikan perlindungan kepada berbagai organisme lain baik hewan darat maupun hewan air untuk bermukim dan berkembang biak, melindungi pantai dari gelombang dan angin merupakan tempat yang dipenuhi pula oleh kehidupan lain seperti mamalia, amfibi, reptil, burung, kepiting, ikan, primata, serangga dan sebagainya. Selain menyediakan keanekaragaman hayati (biodiversity), ekosistem mangrove juga sebagai plasma nutfah (genetic pool) dan menunjang keseluruhan sistem kehidupan di sekitarnya. Habitat mangrove merupakan tempat mencari makan (feeding ground) bagi hewanhewan tersebut dan sebagai tempat mengasuh dan membesarkan anaknya, tempat bertelur dan memijah (spawning ground) dan tempat berlindung yang aman bagi berbagai juvenile dan larva ikan serta kerang (shellfish) dari predator.

Beberapa hewan tinggal di atas pohon mangrove, sebagian lain di antara akar dan lumpur sekitarnya. Walaupun banyak hewan yang tinggal sepanjang tahun, habitat mangrove penting pula untuk pengunjung yang hanya sementara waktu saja, seperti burung yang menggunakan dahan mangrove untuk bertengger atau membuat sarangnya tetapi mencari makan di bagian daratan yang lebih ke dalam, jauh dari daerah habitat mangrove. Kelompok hewan arboreal yang hidup di atas daratan seperti serangga, ular pohon, primata dan burung yang tidak sepanjang hidupnya berada di habitat mangrove, tidak perlu beradaptasi dengan kondisi pasang surut (Nybakken, 1993).

Saling mempengaruhi antar berbagai komponen di hutan mangrove merupakan hal yang penting untuk keberlanjutan dan keseimbangan ekosistem ini. Mangrove tidak lepas dari makhluk hidup lain seperti burung, ular maupun tumbuhan lain selain mangrove itu sendiri. Keberadaan dan peran flora dan fauna yang besar di hutan mangrove perlu mendapat perhatian terutama di ekosistem magrove Gili sulat karena daerah ini merupakan daerah yang potensial untuk penyangga lingkungan dan menjamin terpeliharanya proses ekologis, sebagai ekopariwisata daerah dan sumber belajar bagi siswa, mahasiswa maupun masyarakat secara umum. Wilayah pesisir merupakan suatu daerah peralihan antara ekosistem daratan dan lautan yang memiliki produktivitas hayati tinggi. Adanya pasokan unsur hara dari daratan melalui aliran sungai dan aliran air permukaan ketika hujan, serta tumbuh dan berkembangnya berbagai ekosistem alami seperti hutan mangrove, terumbu karang, padang lamun dan estuaria, menyebabkan wilayah pesisir sangat subur. Dengan potensi tersebut dan aksesibilitasnya yang mudah, wilayah pesisir dimanfaatkan untuk berbagai tujuan.

Sumberdaya pesisir berperan penting dalam mendukung pembangunan ekonomi daerah dan nasional untuk meningkatkan penerimaan devisa, lapangan kerja, dan pendapatan penduduk. Sumberdaya pesisir tersebut mempunyai keunggulan kom-paratif karena tersedia dalam jumlah yang besar dan beranekaragam serta dapat dimanfaatkan dengan biaya eksploitasi yang relatif murah, sehingga mampu menciptakan kapasitas penawaran yang kompetitif. Namun demikian, di balik potensi tersebut, keberadaan sumberdaya sering terancam akibat pembangunan yang tidak berwawasan lingkungan. Dalam dekade terakhir ini, kegiatan pembangunan di wilayah pesisir cukup pesat, baik untuk perikanan, pemukiman, pertambangan, pariwisata dan sebagainya. Pesatnya pembangunan ini serta ditambah dengan tingkat kepadatan penduduk yang tinggi, telah menimbulkan berbagai permasalahan lingkungan di beberapa wilayah pesisir Indonesia. Permasalahan tersebut diantaranya adalah terjadinya degradasi ekosistem alami.

Salah satu ekosistem pesisir yang mengalami tingkat degradasi cukup tinggi akibat pola pemanfaatannya yang cenderung tidak memperhatikan aspek kelestariannya adalah hutan mangrove.

Luas hutan mangrove Indonesia menurut Departemen Kehutanan pada Tahun 1982 sekitar 4,25 juta ha. Hasil Inventarisasi Hutan Nasional yang dilakukan oleh Departemen yang sama 
menyebutkan bahwa luas hutan mangrove Indonesia pada tahun 1996 tinggal 3,53 juta ha. Dengan demikian dalam kurun waktu 14 Tahun Indonesia telah kehilangan hutan mangrove sekitar 700 ribu ha dan hal ini terjadi hampir di seluruh kepulauan Indonesia. Hutan mangrove merupakan salah satu sumberdaya pesisir yang berperan penting dalam pembangunan. Kawasan mangrove sebenarnya mempunyai peranan yang sangat penting bagi manusia dan hewan yang hidup di dalamnya atau sekitarnya, bahkan bagi mahluk hidup yang hanya tinggal untuk sementara waktu.

Berbagai fungsi dan manfaat hutan mangrove bagi manusia dan lingkungan sekitarnya telah diketahui secara umum. Mangrove, magal, bakau, hutan pantai, dan hutan api-api adalah sebutan untuk komunitas tumbuhan pantai yang memiliki adaptasi khusus. Mangrove memegang peranan penting untuk kehidupan laut. Secara ekologis, hutan mangrove dapat menjamin terpeliharanya lingkungan fisik, seperti penahan ombak, angin dan intrusi air laut, serta merupakan tempat perkembangbiakan bagi berbagai jenis kehidupan laut seperti ikan, udang, kepiting, kerang, siput, dan hewan jenis lainnya. Disamping itu, hutan mangrove juga merupakan tempat habitat kehidupan satwa liar seperti monyet, ular, berangberang, biawak, dan burung. Adapun arti penting hutan mangrove dari aspek sosial ekonomis dapat dibuktikan dengan kegiatan masyarakat memanfaatkan hutan mangrove untuk mencari kayu dan juga tempat wisata alam. Selain itu juga sebagai kehidupan dan sumber rezeki masyarakat nelayan dan petani di tepi pantai yang sangat tergantung kepada sumberdaya alam dari hutan mangrove.

Kerusakan ekosistem hutan mangrove di pesisir pantai semakin cepat berlangsung seiring dengan bertambahnya usaha-usaha perekonomian yang lebih mengarah pada daerah pantai. Perubahan-perubahan yang dilakukan terhadap daerah pesisir telah mengorbankan ribuan hektar kawasan mangrove sehingga banyak areal mangrove yang tidak berfungsi lagi sebagaimana mestinya. Kerusakan ini sebagian besar disebabkan oleh tekanan manusia dalam memanfaatkan dan membabat mangrove untuk usaha pertambakan, perindustrian, pertanian, pemukiman, dan tempat rekreasi, serta sebagian kecil karena bencana alam (banjir, kekeringan, dan badai tsunami) serta serangan hama penyakit (Purnobasuki, 2005).
Melihat gejala perusakan hutan mangrove untuk berbagai kepentingan tersebut maka perlu dilakukan pengelolaan hutan mangrove secara lestari. Untuk dapat melakukan pengelolaan hutan mangrove secara lestari diperlukan pengetahuan tentang nilai strategis dari keberadaan hutan mangrove yang bermanfaat bagi masyarakat sekitar. Pengelolaan sumber-daya kelautan berbasis masyarakat merupakan salah satu strategi pengelolaan yang dapat meningkatkan efisiensi dan keadilan dalam pemanfaatan dan pengelolaan sumberdaya alam. Selain itu strategi ini dapat membawa efek positif secara ekologi dan sosial. Pengelolaan sumberdaya alam khususnya sumberdaya kelautan berbasis komunitas lokal sangatlah tepat diterapkan di Indonesia, selain karena efeknya yang positif juga mengingat komunitas lokal di Indonesia memiliki keterikatan yang kuat dengan daerahnya sehingga pengelolaan yang dilakukan akan diusahakan demi kebaikan daerahnya dan tidak sebaliknya. Berangkat dari asumsi bahwa laut tidak semata merupakan sebuah sistem ekologi, tetapi juga sistem sosial. Karena itu, pengembangan kelautan dengan memper-hatikan sistem ekologi-sosial mereka yang khas menjadi penting. Kuatnya institusi lokal di pesisir merupakan pilar bangsa bahari. Bila mereka berdaya, aturan lokal mereka bisa melengkapi kekuatan hukum formal, mereka bisa menjadi pengawas laut yang efektif, menjadi pengelola perikanan lokal karena didukung pengetahuan lokal (traditional ecological knowledge), serta pendorong tumbuhnya ekonomi pesisir.

Pelibatan masyarakat dalam pengembangan dan pengelolaan ekosistem hutan mangrove merupakan langkah strategis dan tepat, selain karena pertimbangan di atas, juga mengingat begitu banyak dan luas pulau-pulau kecil di Indonesia yang sulit diawasi oleh aparat, karena ketebatasan personil dan peralatan. Selain itu, dengan modal pengambangan pengelolaan ekosistem hutan mangrove berbasis masyarakat sekaligus menumbuhkan kedasaran masyarakat akan arti perlindungan sumber daya laut yang sangat berarti bagi kehidupan masyarakat saat ini dan generasi yang akan datang. Tanpa peran serta masyarakat dalam setiap kebijakan pemerintah, tujuan ditetapkannya ke-bijakan tersebut sulit dicapai. Oleh sebab itu, untuk mencegah kerusakan yang lebih parah terhadap sumber daya laut di Indonesia upaya menumbuhkembangkan peran serta 
masyarakat dalam pelaksanaan dan pengawasan kebijakan tersebut harus selalu dilakukan.

\section{b. Kerusakan Ekosistem Mangrove}

Di Indonesia, kerusakan hutan bakau sudah merata di berbagai wilayah. Kerusakan bakau yang tidak sedikit ini sangat banyak menimbulkan kerugian, baik dari segi sosial maupun ekonomi. Dari pandangan nelayan, secara ekonomi kerusakan hutan bakau membuat ratusan nelayan tidak bisa mendapatkan ikan di daerah hutan bakau lagi. Tangkapan kerang, kepiting dan udang berkurang drastis. Dari segi ekologi dan lingkungan, hilangnya kawasan hutan ini menyebabkan berkurang pula nutrien yang memberi asupan pada biota laut lainnya. Perputaran bahan bahan organik seperti karbon, nitrogen, sulfur tidak berjalan dengan sempurna. Hilangnya vegetasi hutan ini menyebabkan beberapa spesies ikan (seperti ikan pesut), kerang dan udang terganggu daur hidupnya, tidak mendapatkan tempat untuk berkembang biak. Tidak hanya biota laut, Bekantan (Nasalis larvatus) yang biasanya hidup di pohon bakau atau pepohonan lain di kawasan mangrove juga terancam punah, karena terancam habitatnya. Spesies lain yang juga terancam antara lain harimau sumatera (Panthera tigris), wilwo (Mycteria cinerea), bubut hitam (Centropus nigrorufus), dan bangau tongtong (Leptoptilus javanicus).

Tidak adanya barisan mangrove, sama dengan tidak adanya 'penjaga pantai'. Mangrove seakan menjadi penjaga daratan dari bahaya-bahaya yang datang dari lautan. Luasan abrasi (terkikisnya daratn oleh air laut) semakin tinggi, dan potensi kerusakan jika terjadi tsunami juga semakin tinggi. Berdasarkan penelitian CIFOR dan USDA yang ada di blog Mongabay, kerusakan pada hutan mangrove memiliki dampak empat kali lebih besar daripada kerusaan pada hutan tropis (pada luasan yang sama).

Banyak bencana dan kerugian yang terjadi akibat rusak/hilangnya hutan bakau, seperti: abrasi pantai, intrusi air laut, banjir, hancurnya pemukiman penduduk diterpa badai laut, hilangnya sumber perikanan alami, hilangnya kemampuan dalam meredam emisi gas rumah kaca. Kondisi tersebut, umumnya disebabkan oleh:

a. Pengambilan/penebangan hutan bakau secara berlebihan

b. Pengalihfungsian hutan mangrove menjadi areal tambak, pemukiman ataupun pertanian dengan tidak memperhatikan asas konservasi dan berkesinambungan

c. Membiarkan wilayah pesisir tandus dan gersang tanpa adanya upaya penghijauan (misal dengan tanaman bakau)

Penyebab dan dampak rusaknya mangrove memegang peranan dan fungsi yang penting di dalam ekosistem, namun nyatanya banyak permasalahan yang terjadi dalam ekosistem hutan mangrove sehingga mengakibatkan rusaknya hutan mangrove tersebut, untuk mengetahui penyebab serta dampak dari rusaknya ekosistem hutan mangrove maka saya akan memaparkannya pada artikel kali ini. Hal-hal utama yang menjadi permasalahan dan penyebab rusaknya hutan mangrove antara lain:

a) Kegiatan Tebang Habis. Kegiatan ini secara langsung ataupun tidak langsung berdampak pada perubahan komposisi tumbuhan; pohonpohon mangrove akan digantikan oleh spesiesspesies yang nilai ekonominya rendah dan hutan mangrove yang ditebang ini tidak lagi berfungsi sebagai daerah mencari makan (feeding ground) dan daerah pengasuhan (nursery ground) yang optimal bagi bermacam ikan dan udang stadium muda yang penting secara ekonomi.

b) Pengalihan aliran air tawar (misalnya pada pembangunan irigasi). Peningkatan salinitas hutan (rawa) mangrove menyebabkan dominasi dari spesies-spesies yang lebih toleran terhadap air yang menjadi lebih asin; ikan dan udang dalam stadium larva dan juvenil mungkin tak dapat mentoleransi peningkatan salinitas, karena mereka lebih sensitive terhadap perubahan lingkungan, selain itu peningkatan salinitas juga akan mengakibatkan menurunnya tingkat kesuburan hutan mangrove karena pasokan zatzat hara melalui aliran air tawar berkurang.

c) Konversi menjadi lahan pertanian, perikanan. Adanya konversi lahan akan mengakibatkan beberapa dampak, yaitu:

1. Terancamnya regenerasi stok-stok ikan dan udang di perairan lepas pantai yang memerlukan hutan (rawa) mangrove sebagai nursery ground larva dan/atau stadium muda ikan dan udang.

2. Pencemaran laut oleh bahan-bahan pencemar yang sebelum hutan mangrove dikonversi dapat diikat oleh substrat hutan mangrove. 
3. Pendangkalan peraian pantai karena pengendapan sedimen yang sebelum hutan mangrove dikonversi mengendap di hutan mangrove.

4. Intrusi garam melalui saluran-saluran alam yang bertahankan keberadaannya atau melalui saluran-saluran buatan manusia yang bermuara di laut.

5. Erosi garis pantai yang sebelumnya ditumbuhi mangrove.

\section{c. Melestarikan Mangrove}

Konservasi hutan mangrove dan sempadan pantai, Pemerintah RI telah menerbitkan Keppres No. 32 tahun 1990. Sempadan pantai adalah kawasan tertentu sepanjang pantai yang mempunyai manfaat penting untuk mempertahankan kelestarian fungsi pantai, sedangkan kawasan hutan mangrove adalah kawasan pesisir laut yang merupakan habitat hutan mangrove yang berfungsi memberikan perlindungan kepada kehidupan pantai dan lautan. Sempadan pantai berupa jalur hijau adalah selebar $100 \mathrm{~m}$ dari pasang tertinggi kea rah daratan. Upaya-upaya yang dapat dilakukan untuk memperbaiki dan melestarikan hutan mangrove antara lain:

1. Penanaman kembali mangrove sebaiknya melibatkan masyarakat. Modelnya dapat masyarakat terlibat dalam pembibitan, penanaman dan pemeliharaan serta pemanfaatan hutan mangrove berbasis konservasi. Model ini memberikan keuntungan kepada masyarakat antara lain terbukanya peluang kerja sehingga terjadi peningkatan pendapatan masyarakat.

2. Pengaturan kembali tata ruang wilayah pesisir: pemukiman, vegetasi, dll. Wilayah pantai dapat diatur menjadi Kota ekologi sekaligus dapat dimanfaatkan sebagai wisata pantai (ekoturisme) berupa wisata alam atau bentuk lainnya.

3. Peningkatan motivasi dan kesadaran masyarakat untuk menjaga dan memanfaatkan mangrove secara bertanggungjawab.

4. Ijin usaha dan lainnya hendaknya memperhatikan aspek konservasi.

5. Peningkatan pengetahuan dan penerapan kearifan local tentang konservasi

6. Peningkatan pendapatan masyarakat pesisir

7. Program komunikasi konservasi hutan mangrove

8. Penegakan hokum
Perbaikkan ekosistem wilayah pesisir secara terpadu dan berbasis masyarakat. Artinya dalam memperbaiki ekosistem wilayah pesisir masyarakat sangat penting dilibatkan yang kemudian dapat meningkatkan kesejahteraan masyarakat pesisir. Selain itu juga mengandung pengertian bahwa konsep-konsep lokal (kearifan lokal) tentang ekosistem dan pelestariannya perlu ditumbuhkembangkan kembali sejauh dapat mendukung program ini.

Hutan mangrove yang dimiliki oleh Indonesia saat ini berkisar 4,3 Juta hektar. Di mata Dunia, negara Indonesia menyumbang 19\% hutan Mangrove. Hutan mangrove banyak dijumpai di daerah pantai maupun terestial (daratan). Hutan magrove merupakan tanaman yang hidup di air payau, air asin (laut), serta daerah daratan (terestial).

Jenis pohon magrove banyak ragamnya, sesuai daerah endemik masing-masing wilayah seperti dikenal adanya mangrove bogem, Rhizopora (bakau-bakau), berembang, api-api, pidada, dan lainnya. Banyak sekali manfaat hutan magrove bagi kehidupan seperti buahnya dapat dijadikan minuman segar (jus) buah pidada yang kaya akan vitamin $\mathrm{C}$, menjaga luasan tanah agar tidak dibuka lahan baru, sebagai penahan racun dan logam berat di daerah lautan, menjaga abrasi air laut dan tsunami, sebagai plasma nutfah, sebagai tempat budidaya kepiting dengan proses pertambakan, memberi pendapatan tambahan masyarakat sekitar daerah pesisir pantai, serta menjaga keseimbangan ekosistem dan keanekaragaman hayati lainnya.

WWF (Organisasi konservasi independen terbesar di Indonesia dan telah memulai kegiatannya sejak 1962) di Indonesia, mengatakan bahwa upaya melestarikan hutan mangrove sangat penting dengan melibatkan rakyat, pemerintah, individu itu sendiri, serta korporasi lainnya. Agar tanaman mangrove tidak rusak cara mencegahnya yaitu mengikutsertakan masyarakat dan memberikan bimbingan dan bekal ilmu kepada mereka, mensinergikan antara tanaman mangrove dengan tambak, menjadikan mangrove sebagai sumber kehidupan masyarakat, serta bagaimana masyarakat itu sendiri dapat menanamkan rasa peduli, rasa memiliki terhadap pentingnya tanaman magrove sehingga kelestariannya dapat diperjuangkan. Lebih lanjut menurutnya, kategori hutan mangrove saat ini banyak yang rusak (33\%), serta sangat rusak (42\%). Sementara itu, ancaman hutan mangrove berasal dari ulah tangan manusia 
itu sendiri (perambahan) dan ancaman dari alam (distraktif).

Efektivitas dan upaya melestarikan hutan mangrove di Indonesia sangat penting. Hal ini dapat dilakukan program sosialisasi kepada pemerintah, masyarakat, mahasiswa, pelajar, dan stake holder terkait lainnya. Jika mangrove dikelola dengan baik maka pantai t akan mampu menjadi tempat pendidikan (edukasi), penelitian, bahkan pengembangan hutan mangrove yang berkelanjutan. Proyeksi dari keberadaan hutan mangrove di Indonesia diantaranya jumlahnya semakin banyak, membuka peluang kepada koporasi untuk dapat bekerjasama termasuk melibatkan pemerintah dan masyarakat pesisir pantai untuk ikut berpartisipasi dalam menanam pohon mangrove.
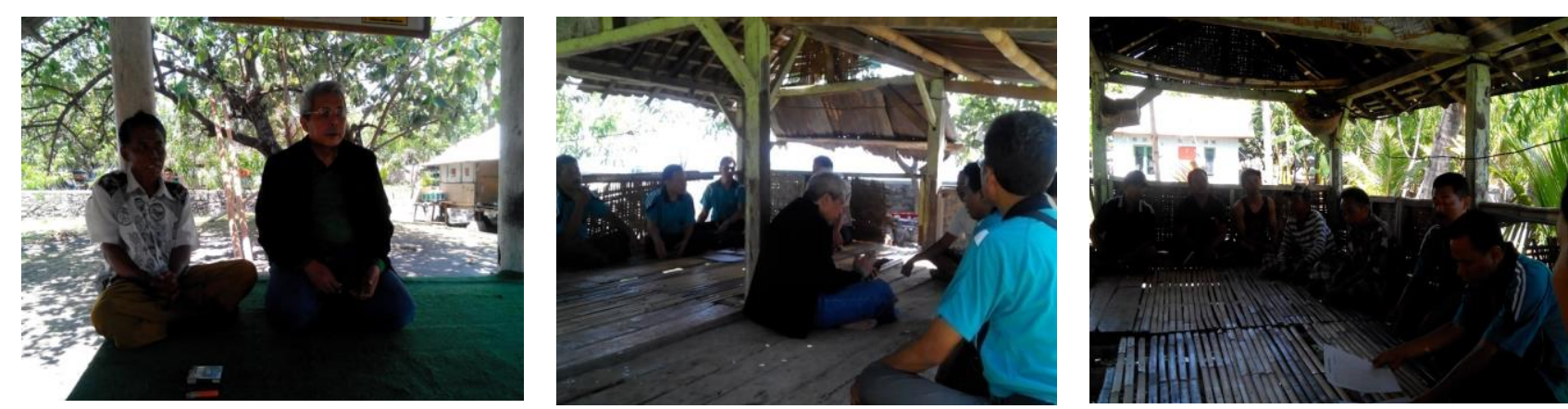

Gambar 1 Penyampaian Materi Sosialisasi
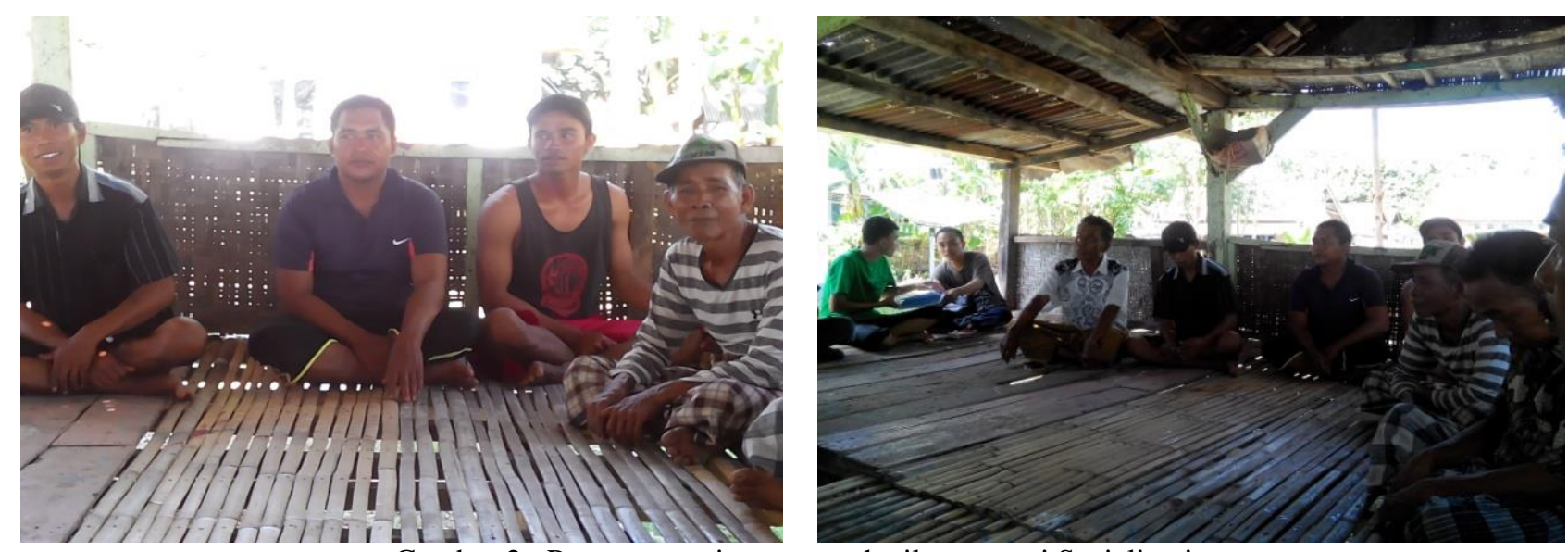

Gambar 2 : Peserta antusias memperhatikan materi Sosialisasi
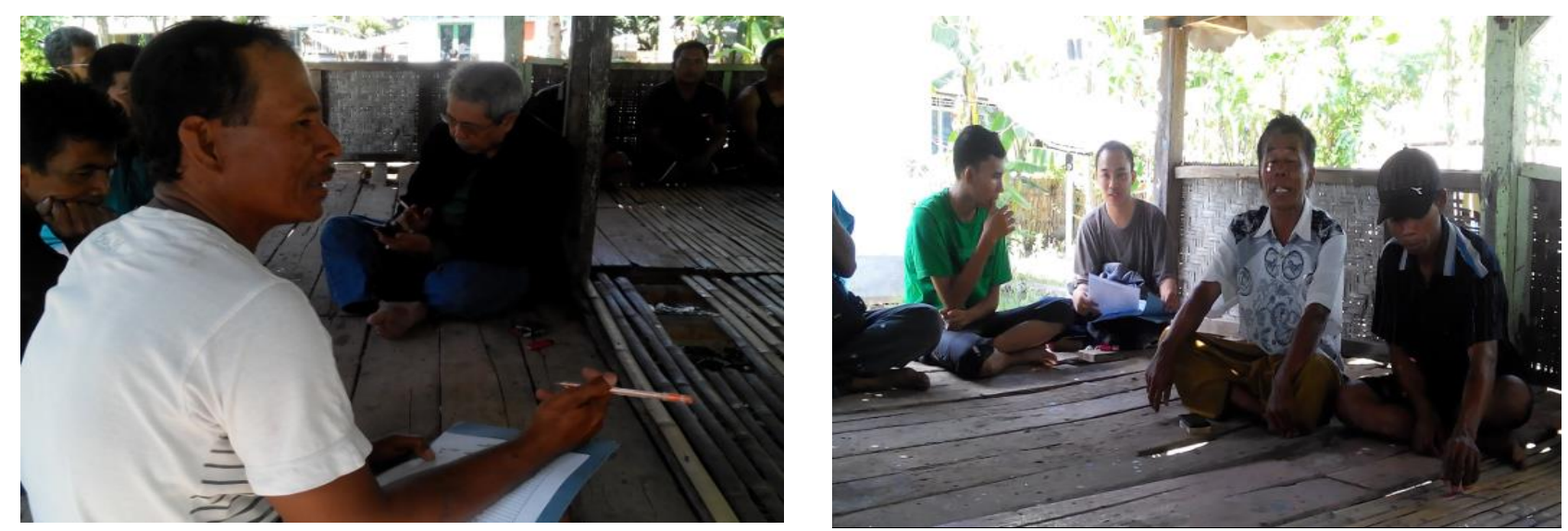

Gambar 3 Diskusi dan Tanya jawab tentang materi sosialisasi 


\section{Kesimpulan}

Serangkaian kegiatan pengabdian pada masyarakat ini telah berlangsung dapat diambil kesimpulan sebagai berikut: (1) semua peserta yang terdiri dari warga masyarakat dan kelompok nelayan sangat antusias mengikuti seluruh rangkaian kegiatan dengan memberikan respon positif selama kegiatan berlangsung, (2) tim Pengabdian memaparkan dan memberikan sosialisasi peran dan fungsi mangrove pada masyarakat kawasan Gili Sulat Lombok Timur dan peserta aktif menanyakan hal-hal yang belum jelas dari materi sosialisasi dan (3) setelah sosialisasi, semua peserta sangat termotivasi untuk tetap mempertahankan keberadaan mangrove di Gili Sulat agar lestari.

\section{Ucapan Terima Kasih}

Tim pengabdian pada masyarakat menyampaikan ucapan terima kasih kepada Bapak Rektor Universitas Mataram yang telah memberikan bantuan dana untuk pelaksanaan kegiatan pengabdian pada masyarakat ini melalui sumber dana PNBP Universitas Mataram 2015.

\section{Daftar Pustaka}

Agil, Al- I., Hadiprayitno, G., IL-Hamdi, M.L., dan Gde Mertha, G. 2014, Inventarisasi Flora Dan Fauna Di Kawasan Mangrove Gili Sulat Untuk Pengembangan Bahan Ajar Ekologi Dan Penunjang Ekowisata NTB, Laporan Penelitian Universitas Mataran, Mataram.

Agil-Al, I., Hadiprayitno, G., Mertha, I.G., dan IlHamdi, M.L. 2015. Potensi Vegetasi dan Arthropoda di Kawasan Mangrove Gili Sulat Lombok Timur. Jurnal Bioogi Tropis, 15 (2): 183-196

Arief. 2007. Hutan Mangrove, Fungsi dan Manfaatnya, Kanisius, Yogyakarta.

Khairuddin, Yamin, M. dan Syukur, A. 2018. Analisis Kandungnan Logam Berat pada Tumbuhan Mangrove Sebagai Bioindikator di Teluk Bima. Jurnal Biologi Tropis, 18 (1): 6-79.
Kristanti, R. A, Mursidi dan Sarwono, 2007. Kandungan Beberapa Logam Berat Pada Bakau (Rhizophora Apiculata) di Perairan Bontang Selatan, Kalimantan Timur. Jurnal Kehutanan Unmul: 3 (2): 16-22

Oktober 2007.Nur, M., Nasruddin, Wasiq, J., \& Sumariyah. 2013. Penerapan Teknologi Plasma untuk Mempercepat Persemaian Mangrove sebagai Upaya Rehabilitasi Green Belt untuk Mengatasi Abrasi. Riptek Vol. 7 (1): 15 - 26.

Nybakken, J.W. 1993. Marine Biology: An Ecological Approach. Terjemahan Dr. M. Eidman. Gramedia Jakarta.

Santoso, N. 2000. Pola Pengawasan Ekosistem Mangrove. Makalah disampaikan pada Lokakarya Nasional Pengembangan Sistem Pengawasan Ekosistem Laut Tahun 2000. Jakarta, Indonesia.

Tahmid, M., Fahrudin, A., dan Wardiatno, Y. 2015. Kajian Struktur Ukuran Dan Parametr Populasi Kepiting Bakau (Scylla serrata) di Ekosistem Mangrove Teluk Bintan, Kepulauan Riau. Jurnal Biologi Tropis, 15 (2): 1-11. 